\title{
Horizontal and Vertical Distribution of Heavy Metals in Farm Produce and Livestock around Lead-Contaminated Goldmine in Dareta and Abare, Zamfara State, Northern Nigeria
}

\author{
O. E. Orisakwe, ${ }^{1}$ O. O. Oladipo, ${ }^{2}$ G. C. Ajaezi, ${ }^{3}$ and N. A. Udowelle ${ }^{1}$ \\ ${ }^{1}$ Toxicology Unit, Faculty of Pharmacy, University of Port Harcourt, Rivers State, Nigeria \\ ${ }^{2}$ National Veterinary Research Institute, Vom, Nigeria \\ ${ }^{3}$ Department of Medical Laboratory Science, Faculty of Science, Rivers State University of Science and Technology, \\ Port Harcourt, Rivers State, Nigeria \\ Correspondence should be addressed to O. E. Orisakwe; orishebere@gmail.com
}

Received 28 December 2016; Accepted 6 April 2017; Published 2 May 2017

Academic Editor: Evelyn O. Talbott

Copyright (C) 2017 O. E. Orisakwe et al. This is an open access article distributed under the Creative Commons Attribution License, which permits unrestricted use, distribution, and reproduction in any medium, provided the original work is properly cited.

\begin{abstract}
Background. Hitherto studies in response to the June 2010 lead poisoning, Zamfara State, Nigeria, have focused on clinical interventions without information on livestock and other metals. Objective. This study has investigated the distribution of heavy metals in farm produce and livestock around lead-contaminated goldmine in Dareta and Abare, Zamfara State, Nigeria. Methods. Vegetables, soil, water, blood, and different meat samples were harvested from goat, sheep, cattle, and chicken from Dareta, Abare, and Gusau communities. The samples were digested with $10 \mathrm{~mL}$ of a mix of nitric and perchloric acids; the mixture was then heated to dryness. Lead, cadmium, zinc, chromium, copper, magnesium, and nickel were analysed using flame Atomic Absorption Spectrophotometer. The daily intake, bioaccumulation factor, and target hazard quotient (THQ) were calculated. Results. Chicken bone-muscles from Dareta had the highest concentrations of lead, zinc, and nickel (28.2750,16.1650, and 4.2700 mg/kg, resp.), while chicken brain had the highest levels of cadmium, magnesium $(0.3800$ and $67.5400 \mathrm{mg} / \mathrm{kg})$, and chromium $(6.1650 \mathrm{mg} / \mathrm{kg}$, kidney tissue inclusive). Conclusion. In addition to lead, cadmium may also be of concern in the contaminated mining communities of Zamfara State, Nigeria, given the high levels of cadmium in meat and vegetables samples from these areas.
\end{abstract}

\section{Introduction}

In early 2010, an epidemic of lead poisoning was discovered during routine meningitis surveillance in Zamfara State, Nigeria, conducted during February-April 2010, Médecins Sans Frontières (MSF) and local public health officials identified more than 200 children ( $<5$ years old) with history of convulsions during the previous 3 months in four villages.

Zamfara State is located in northwestern Nigeria with a population of about four million people (Joint United Nations Environment Programme/Office for the Coordination of Humanitarian Affairs Environment Unit 2010). Although farming is the major livelihood of the local population, Zamfara has been the scene of artisanal gold mining for decades.

Risk assessment, contaminant characterization, and remedial assessment studies done from May 2010 to July
2011 confirmed that the primary exposure route is the incidental ingestion of lead-contaminated soils and household dust [1]. Contamination of food sources during food preparation and processing, inhalation of contaminated dust, and consumption of contaminated water are secondary exposure pathways that magnify lead intake for the exposed populations [1]. Heavy metals precipitate onto topsoil to increase the human health risk, and this risk is then magnified by the accumulation of heavy metals into plants grown on this topsoil. Indeed, vegetables and fruits can contain high levels of heavy metals [2]. In addition to lead, other heavy metals may be present in the ores, including but not limited to cadmium, zinc, chromium, copper, and nickel. Lead is the primary toxicant of concern and remediation removes secondary heavy metals while targeting lead. However, the overall risk to the populations is not limited to 
lead poisoning. The public health effects of lead exposure to adult and children are documented in literature; however, the combined effects of coexposure to a mixture of heavy metals is largely unknown, especially for intense, chronic exposures.

Lead ingestion or inhalation can cause damage to the brain, kidneys, bone marrow, and other body systems in young children. In infants and children, blood lead levels (BLLs) as low as $5 \mu \mathrm{g} / \mathrm{dL}$ have been associated with developmental problems, including impaired cognitive function, behavioral difficulties, impaired hearing, and reduced stature [3]. BLLs $\geq 75 \mu \mathrm{g} / \mathrm{dL}$ can cause coma, convulsions, and death. From studies on pre- and postnatal cadmium exposure and IQ deficits, cadmium has been reported to be a potential neurotoxicant. Developmental exposure in laboratory animals indicates that operant performance and conditioned avoidance are negatively impacted as well [4]. Cadmium appears to cross the placental barrier and accumulate in the foetus resulting in neurodevelopmental toxicity [5].

Nickel is an essential trace element in animals, although the functional importance of nickel has not been clearly demonstrated. Although other heavy metals may be involved, nickel seems to be implicated in chronic bronchitis, emphysema, pulmonary fibrosis, and impaired lung function [6]. Copper and chromium are very important essential elements in man but excessive intakes have long been associated with toxicity [7]. Copper is a component of enzymes in iron metabolism and deficiency of this element causes anaemia [7]. Chromium helps to maintain normal blood glucose level and is widely used in diabetes medications [8]. Toxicity of copper and chromium occurs in both acute and chronic forms in cases of excessive intakes [9-11]. Acute copper toxicity signs are nausea, vomiting, jaundice and liver necrosis, damage to the proximal tubules of the kidney, and haemolytic anaemia [9-11]. Wilson's disease in man is a form of chronic copper toxicity with clinical signs including mental alterations, motor abnormalities, dysphagia, ataxia, haemolytic anaemia, renal dysfunction, renal stones, and hepatic failure [9]. Normally chromium toxicity is due to physical contact with contaminated dust or soil resulting in allergic dermatitis characterized by eczema [10].

Whereas most studies in response to the Zamfara lead poisoning have been centered on clinical intervention and reduction of blood lead level (BLL) in children, [12] highlighted the limitations as follows: nonassessment of lead poisoning in livestock in other foods including dairy products. Since many villagers may be exposed through consumption of lead-contaminated foods, [12] recommended the need to characterise the depth and extent of lead distribution in livestock. It is also known that lead does not exist alone in the earth crust and several cases of lead intoxication occur as a cocktail of heavy metal mixture. The present study is aimed at addressing the limitations of [12] study with an investigation into the horizontal and vertical distribution of heavy metals in farm produce and livestock around leadcontaminated goldmine in Dareta and Abare, Zamfara State, Northern Nigeria.

\section{Materials and Methods}

A cross-sectional study was carried out in June 2010 in Zamfara State, Nigeria. After focus group discussions with community heads, representatives of the pastoralist, gold miners/processors, the following sampling sites (Dareta, Abare, and Gusau; Figure 1) were chosen. Two hundred milligrams of liver, spleen, kidney, lungs, skeletal muscle, and brain of cattle, sheep, goat, and chicken were harvested. Blood samples $(5 \mathrm{mls})$ of cattle, sheep, goat, and chicken were also taken. Vegetable, pasture soil, and water (waste and drinking) were also collected for lead, cadmium, zinc, chromium, copper, magnesium, and nickel analyses.

\subsection{Study Area and Sampling}

2.1.1. Sample Preparation. Samples were first washed with deionised water. All samples were oven-dried at $70-80^{\circ} \mathrm{C}$ for 24 hours. Dried samples were ground using a pestle and mortar and sieved through muslin cloth. The protocol was approved by the Research Ethical Committee of the University of Port Harcourt, Rivers State, Nigeria.

2.1.2. Sample Digestion. Five milliliters each of the water samples was acidified to the level of $\mathrm{pH} 2$ with nitric acid.

For each tissue sample or grass, $0.2 \mathrm{~g}$ each was weighed and placed in crucibles for ashing in a furnace for $4 \mathrm{~h}$ at $550^{\circ} \mathrm{C}$. The ash was digested with perchloric acid and nitric acid $(1: 4$, $\mathrm{v}$ : v) solution. The samples were left to cool and made up to a final volume of $25 \mathrm{ml}$ with deionised water. The hydrolysed samples were well shaken and centrifuged at the rate of $3000 \mathrm{~g}$ to remove solid particles. The resulting homogenized samples were vortex mixed before subsamples were taken for analysis to ensure the homogeneity of the mixture.

The presence of lead, cadmium, zinc, chromium, copper, magnesium, and nickel was analysed using flame Atomic Absorption Spectrophotometer according to the specification of the manufacturer (Shimadzu AAS 6800 B Model). The limits of detection for the toxic metals were all $0.005 \mathrm{ppm}$ with blank values reading as $0.00 \mathrm{ppm}$ for all the metals in deionised water with electrical conductivity value lower than $5 \mu \mathrm{S} \mathrm{cm}^{-1}$.

2.2. Quality Control. Appropriate quality procedures and precautions were carried out to assure the reliability of the results. The reagents used to calibrate the instrumentation were of analytical grades. Quality assurance measures were taken to reduce the risk of contamination in order to ensure the reliability of data.

\section{Data Analyses}

3.1. Daily Metals Intake Estimate. The daily intake was calculated by the following equation [23]:

$$
\text { DMI }(\mathrm{mg} / \text { day })=\frac{C_{\text {metal }} \times D_{\text {intake }}}{B_{\text {weight }}},
$$

where $C_{\text {metal }}$ is the metal concentration in sample taken for analysis (in $\mathrm{mg} / \mathrm{kg}$ ). $B_{\text {weight }}$ is the body weight ( $6 \mathrm{~kg}$ in this 


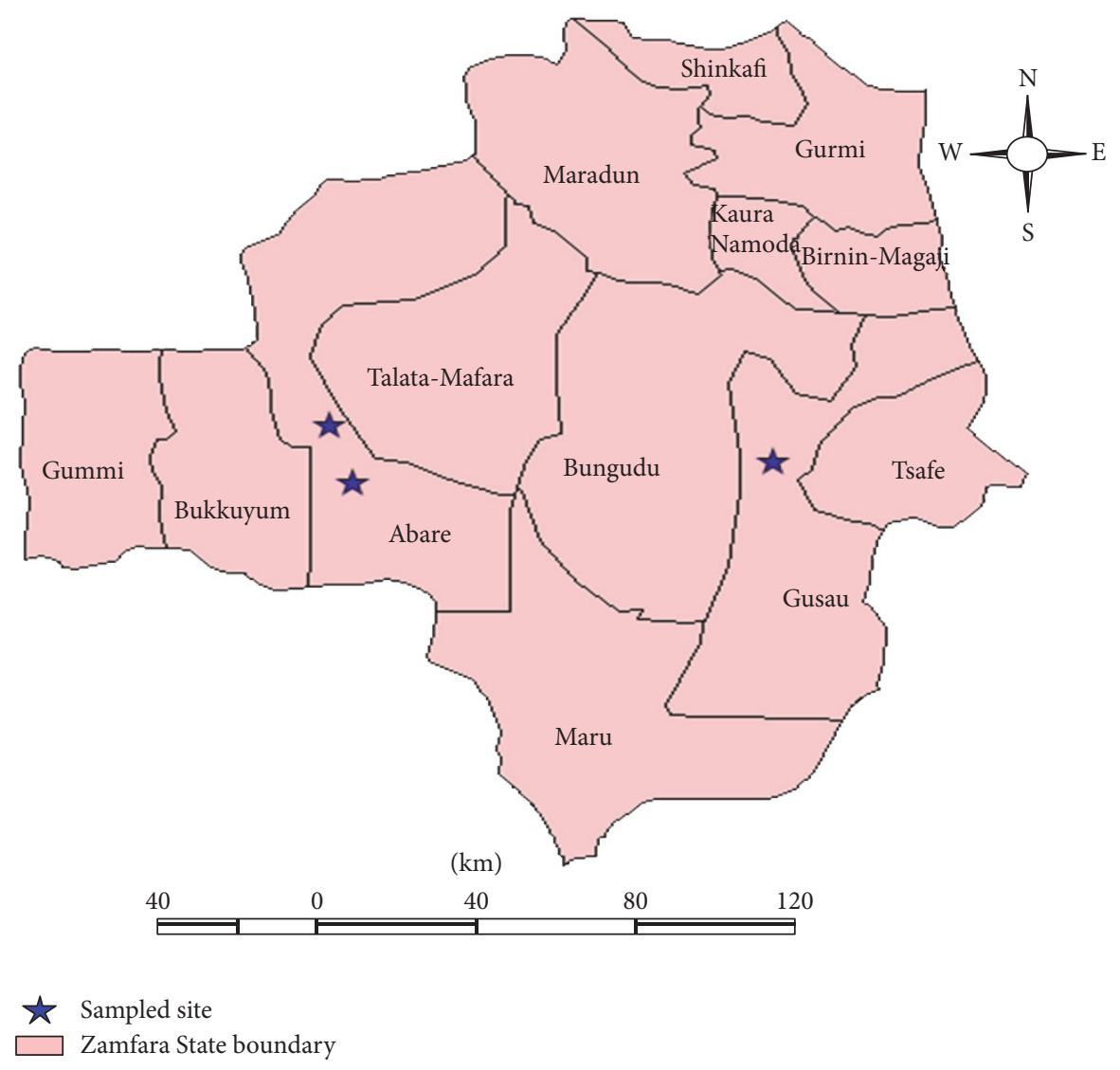

FIGURE 1: Map of Zamfara State showing local government areas and sampling sites.

study). $D_{\text {intake }}$ is the daily intake $(0.345 \mathrm{~kg} /$ person/day) [24, 25].

3.2. Target Hazard Quotient (THQ) and Total THQ. Target hazard quotients were developed by the Environmental Protection Agency (EPA) in the US for the estimation of potential health risks associated with long-term exposure to chemical pollutants [26]. This includes not only the intake of metals but also another significant data as exposure frequency and duration, body weight, and the oral reference dose (RfD). The THQ is a ratio between the measured concentration and the oral reference dose (RfD), weighted by the length and frequency of exposure, amount ingested, and body weight. The THQ $<1$ means the exposed population is assumed to be safe and $1<$ THQ $<5$ means that the exposed population is in a level of concern interval. THQ parameter is a dimensionless index and THQ values are additive, but not multiplicative. It must be noted that THQ is not a measure of risk but indicates a level of concern. THQ was determined based on the formula (modified) given by [27]:

$$
\mathrm{THQ}=\left(\frac{\mathrm{EFr} \times \mathrm{ED}_{\text {tot }} \times \mathrm{FIR} \times \mathrm{C}}{\mathrm{RfD}_{\mathrm{o}} \times \mathrm{BW}_{\mathrm{a}} \times \mathrm{AT}_{\mathrm{n}}}\right) \times 10^{-3},
$$

where the parameter values are the following: EFr, exposure frequency $=365$ days/year; $\mathrm{ED}_{\text {tot }}$, exposure duration $=70$ years, equivalent to average lifetime [28]; FIR, food ingestion rate $=0.345 \mathrm{~kg} /$ person$/$ day $[24,25] ; C$, concentration of metal in animal tissue in $\mathrm{mg} / \mathrm{kg} ; \mathrm{RfD}_{\mathrm{o}}$, oral reference dose in $\mathrm{mg} / \mathrm{kg} /$ day; $\mathrm{BW}_{\mathrm{a}}$, average body weight, adult $=60 \mathrm{~kg} ; \mathrm{AT}_{\mathrm{n}}$, average exposure time for noncarcinogens in days (EFr (365 days/year) $\times \mathrm{ED}_{\text {tot }}$ (number of exposure years, assuming 70 years in this study); $10^{-3}$, the unit of conversion).

The total THQ (TTHQ) of heavy metals for the individual parameter assayed was calculated according to [27] as the sum of the individual THQ of the heavy metals.

The total THQ is the sum of the following compositions:

$$
\begin{aligned}
\text { Total THQ }(\text { TTHQ })= & \text { THQ }(\text { toxicant } 1) \\
& + \text { THQ }(\text { toxicant } 2)+\cdots \\
& + \text { THQ (toxicant } n) .
\end{aligned}
$$

The data were also analysed using GraphPad InStat version 6.03 statistical package to obtain the mean, standard deviation, standard error of the mean, range, and the linear correlation between the measured parameters.

3.3. Bioaccumulation Factor (BAF). The bioaccumulation factor (BAF), an index of the ability of the vegetables to accumulate a particular metal with respect to its concentration in the soil substrate, was calculated as follows:

$$
\mathrm{BAF}=\frac{C_{\text {grass }}}{C_{\text {soil }}},
$$


TABLE 1: Blood levels ( $\mathrm{mg} / \mathrm{kg}$ ) of heavy metals in goat, sheep, cattle, and chicken from Dareta, Abare, and Abattoir.

\begin{tabular}{|c|c|c|c|c|c|}
\hline Element & Animal & Location & $N$ & Mean \pm SD & Range (Min-Max) \\
\hline \multirow{6}{*}{$\mathrm{Pb}$} & \multirow{2}{*}{ Goat } & Dareta & 13 & $7.7554 \pm 7.4943$ & $2.0000-30.2750$ \\
\hline & & Abare & 3 & $5.0867 \pm 2.9326$ & $1.7500-7.2550$ \\
\hline & Sheep & Dareta & 2 & $6.2550 \pm 4.6033$ & $3.0000-9.5100$ \\
\hline & \multirow{2}{*}{ Cattle } & Dareta & 2 & $5.7550 \pm 7.0781$ & $0.7500-10.7600$ \\
\hline & & Abattoir & 4 & $4.7538 \pm 5.4933$ & $0.5000-12.5100$ \\
\hline & Chicken & Dareta & 6 & $4.4608 \pm 3.1066$ & $0.7500-8.2550$ \\
\hline \multirow{6}{*}{$\mathrm{Cd}$} & \multirow{2}{*}{ Goat } & Dareta & 13 & $0.2835 \pm 0.1446$ & $0.0900-0.6150$ \\
\hline & & Abare & 3 & $0.2433 \pm 0.1589$ & $0.1300-0.4250$ \\
\hline & Sheep & Dareta & 2 & $0.2150 \pm 0.1344$ & $0.1200-0.3100$ \\
\hline & \multirow{2}{*}{ Cattle } & Dareta & 2 & $0.2950 \pm 0.3323$ & $0.0600-0.5300$ \\
\hline & & Abattoir & 4 & $0.2363 \pm 0.2299$ & $0.0000-0.5150$ \\
\hline & Chicken & Dareta & 6 & $0.3258 \pm 0.2001$ & $0.1750-0.7200$ \\
\hline \multirow{6}{*}{$\mathrm{Zn}$} & \multirow{2}{*}{ Goat } & Dareta & 13 & $1.7908 \pm 1.5463$ & $0.0000-5.3600$ \\
\hline & & Abare & 3 & $1.8233 \pm 0.8498$ & $0.8650-2.4850$ \\
\hline & Sheep & Dareta & 2 & $1.4125 \pm 0.2793$ & $1.2150-1.6100$ \\
\hline & \multirow{2}{*}{ Cattle } & Dareta & 2 & $0.7050 \pm 0.9334$ & $0.0450-1.3650$ \\
\hline & & Abattoir & 4 & $2.0400 \pm 2.4436$ & $0.0000-5.5900$ \\
\hline & Chicken & Dareta & 6 & $0.7217 \pm 0.2481$ & $0.4450-1.0450$ \\
\hline \multirow{6}{*}{$\mathrm{Cr}$} & \multirow{2}{*}{ Goat } & Dareta & 13 & $2.9219 \pm 1.1640$ & $0.8800-5.2850$ \\
\hline & & Abare & 3 & $2.7683 \pm 0.5477$ & $2.1400-3.1450$ \\
\hline & Sheep & Dareta & 2 & $2.8925 \pm 0.1803$ & $2.7650-3.0200$ \\
\hline & \multirow{2}{*}{ Cattle } & Dareta & 2 & $2.3275 \pm 0.9793$ & $1.6350-3.0200$ \\
\hline & & Abattoir & 4 & $3.2375 \pm 3.4230$ & $0.1250-4.1500$ \\
\hline & Chicken & Dareta & 6 & $2.4317 \pm 1.5375$ & $0.6300-3.6500$ \\
\hline \multirow{6}{*}{$\mathrm{Cu}$} & \multirow{2}{*}{ Goat } & Dareta & 13 & $1.1123 \pm 0.6844$ & $0.4900-3.1650$ \\
\hline & & Abare & 3 & $0.9300 \pm 0.1440$ & $0.8300-1.0950$ \\
\hline & Sheep & Dareta & 2 & $1.1300 \pm 0.5869$ & $0.7150-1.5450$ \\
\hline & \multirow{2}{*}{ Cattle } & Dareta & 2 & $1.0150 \pm 0.0000$ & - \\
\hline & & Abattoir & 4 & $1.4788 \pm 0.3307$ & $1.2450-1.9800$ \\
\hline & Chicken & Dareta & 6 & $0.7733 \pm 0.2059$ & $0.5300-1.0950$ \\
\hline \multirow{6}{*}{$\mathrm{Mg}$} & \multirow{2}{*}{ Goat } & Dareta & 13 & $2.9219 \pm 1.1640$ & $0.8800-5.2850$ \\
\hline & & Abare & 3 & $19.6133 \pm 1.3247$ & $18.0900-20.4950$ \\
\hline & Sheep & Dareta & 2 & $9.6100 \pm 13.5906$ & $0.0000-19.2200$ \\
\hline & \multirow{2}{*}{ Cattle } & Dareta & 2 & $13.8125 \pm 8.3615$ & $7.9000-19.7250$ \\
\hline & & Abattoir & 4 & $19.2600 \pm 1.0357$ & $17.7900-20.1300$ \\
\hline & Chicken & Dareta & 6 & $2.6058 \pm 0.7654$ & $1.5700-3.1250$ \\
\hline \multirow{6}{*}{$\mathrm{Ni}$} & \multirow{2}{*}{ Goat } & Dareta & 13 & $1.7869 \pm 1.6479$ & $0.0500-5.7800$ \\
\hline & & Abare & 3 & $3.9583 \pm 3.0875$ & $0.6250-6.7200$ \\
\hline & Sheep & Dareta & 2 & $2.0050 \pm 1.5839$ & $0.8850-3.1250$ \\
\hline & \multirow{2}{*}{ Cattle } & Dareta & 2 & $1.4325 \pm 0.4773$ & $1.0950-1.7700$ \\
\hline & & Abattoir & 4 & $1.1725 \pm 1.0281$ & $0.0000-2.5000$ \\
\hline & Chicken & Dareta & 6 & $1.9267 \pm 0.9005$ & $1.3000-3.7000$ \\
\hline
\end{tabular}

where $C_{\text {grass }}$ and $C_{\text {soil }}$ represent the heavy metal concentration in grass and soil, respectively.

\section{Results}

Table 1 gives the mean blood levels of the heavy metals, namely, lead, cadmium, zinc, chromium, copper, magnesium, and nickel in the sampled goat, sheep, cattle, and chicken, and the levels of individual sample variability from one another as well as dispersion from sampling size. Goat and chicken (blood) from Dareta had the highest mean concentrations of lead and cadmium (7.7554 and $0.3258 \mathrm{mg} / \mathrm{kg}$, resp.), while cattle from Abattoir had the highest mean blood levels for zinc $(2.0400 \mathrm{mg} / \mathrm{kg})$, chromium $(3.2375 \mathrm{mg} / \mathrm{kg})$, and copper $(1.4788 \mathrm{mg} / \mathrm{kg})$. Goat from Abare had the mean maximum values for magnesium and nickel $(19.6133$ and $3.9583 \mathrm{mg} / \mathrm{kg}$, 
TABLE 2: Mean concentrations $(\mathrm{mg} / \mathrm{kg}$ ) of heavy metals in some physical samples.

\begin{tabular}{|c|c|c|c|c|}
\hline Element & Environmental matrix & $N$ & Mean \pm SD & Range (Min-Max) \\
\hline \multirow{3}{*}{$\mathrm{Pb}$} & Vegetable & 5 & $51.343 \pm 42.634$ & $11.010-102.840$ \\
\hline & Soil & 4 & $46.039 \pm 29.420$ & $5.755-76.065$ \\
\hline & Water & 6 & $1.301 \pm 2.159$ & $0.040-5.505$ \\
\hline \multirow{3}{*}{$\mathrm{Cd}$} & Vegetable & 5 & $0.288 \pm 0.069$ & $0.220-0.380$ \\
\hline & Soil & 4 & $0.360 \pm 0.122$ & $0.250-0.500$ \\
\hline & Water & 6 & $0.058 \pm 0.102$ & $0.008-0.265$ \\
\hline \multirow{3}{*}{$\mathrm{Zn}$} & Vegetable & 5 & $4.593 \pm 1.600$ & $3.205-6.910$ \\
\hline & Soil & 4 & $3.000 \pm 3.802$ & $0.405-8.640$ \\
\hline & Water & 6 & $0.228 \pm 0.256$ & $0.041-0.575$ \\
\hline \multirow{3}{*}{$\mathrm{Cr}$} & Vegetable & 5 & $3.597 \pm 1.466$ & $2.010-5.535$ \\
\hline & Soil & 4 & $14.655 \pm 17.211$ & $4.530-40.250$ \\
\hline & Water & 6 & $1.324 \pm 2.077$ & $0.141-5.285$ \\
\hline \multirow{3}{*}{$\mathrm{Cu}$} & Vegetable & 5 & $10.069 \pm 10.450$ & $1.695-23.815$ \\
\hline & Soil & 4 & $1.970 \pm 1.539$ & $0.530-4.145$ \\
\hline & Water & 6 & $0.354 \pm 0.483$ & $0.030-1.015$ \\
\hline \multirow{3}{*}{$\mathrm{Mg}$} & Vegetable & 5 & $68.463 \pm 7.074$ & $55.840-72.095$ \\
\hline & Soil & 4 & $41.508 \pm 29.73$ & $2.659-70.845$ \\
\hline & Water & 6 & $17.836 \pm 14.645$ & $0.861-34.920$ \\
\hline \multirow{3}{*}{$\mathrm{Ni}$} & Vegetable & 5 & $2.814 \pm 0.768$ & $1.720-3.805$ \\
\hline & Soil & 4 & $2.174 \pm 1.601$ & $0.675-4.375$ \\
\hline & Water & 6 & $1.155 \pm 1.395$ & $0.105-3.540$ \\
\hline
\end{tabular}

resp.). Goats from Dareta had the highest amounts of blood lead and copper $(30.2750$ and $3.1650 \mathrm{mg} / \mathrm{kg})$, and chicken from Dareta had blood cadmium $(0.7200 \mathrm{mg} / \mathrm{kg})$, while cattle from Abattoir had the highest blood levels of both zinc and chromium (5.5980 and $7.6700 \mathrm{mg} / \mathrm{kg}$, resp.) (table not shown). Goats from Abare had the highest blood levels of magnesium and nickel (20.4950 and $6.7200 \mathrm{mg} / \mathrm{kg}$, resp.) (table not shown). The blood levels of lead in goats from Dareta and Abare are 7.7554 and $5.0867 \mathrm{mg} / \mathrm{kg}$, respectively. Sheep and cattle from Dareta had blood lead levels of 6.2550 and $5.755 \mathrm{mg} / \mathrm{kg}$, respectively (table not shown).

Table 2 presents the mean concentrations of the heavy metals lead, cadmium, zinc, chromium, copper, magnesium, and nickel in some of the environmental matrices (vegetable, plant, soil, and water) and the levels of individual sample variability from one another as well as dispersion from sampling size. The minimum and the maximum values are also indicated in form of ranges. The mean concentrations of magnesium in both the vegetable and water samples were the most elevated (68.463 and $17.836 \mathrm{mg} / \mathrm{kg}$, resp.). Soil sample had the highest mean concentration of lead $(46.039 \mathrm{mg} / \mathrm{kg})$. Vegetable from Dareta had the most elevated levels of lead, copper, and magnesium (102.8350, 23.8150, and $72.0950 \mathrm{mg} / \mathrm{kg}$, resp.), while soil samples from Dareta (cadmium and chromium, 0.5000 and $40.2500 \mathrm{mg} / \mathrm{kg}$ ) and Abare (zinc and nickel, 8.6400 and $4.3750 \mathrm{mg} / \mathrm{kg}$ ) had the highest concentrations, respectively (not shown in the table).

The oral reference doses (RfD), the highest estimated daily intake, and upper tolerable daily intakes for metals (UL) are presented in Table 3. No RfD has been set by USEPA for magnesium.
TABLE 3: Oral reference doses (RfD), highest estimated daily intake, and upper tolerable daily intakes (UL) for investigated metals.

\begin{tabular}{|c|c|c|c|c|}
\hline $\mathrm{S} / \mathrm{N}$ & Element & $\begin{array}{c}\mathrm{RfD} \\
(\mathrm{mg} / \mathrm{kg} / \text { day }) \\
{[13]}\end{array}$ & $\begin{array}{c}\text { Highest } \\
\text { estimated daily } \\
\text { intake } \\
\text { (mg/day) }\end{array}$ & $\begin{array}{l}\mathrm{UL} \text { (mg/day) } \\
\text { [references] }\end{array}$ \\
\hline 1 & $\mathrm{~Pb}$ & 0.004 & 0.1626 & $\begin{array}{c}0.4[14] \\
0.5[15,16]\end{array}$ \\
\hline 2 & $\mathrm{Cd}$ & 0.001 & 0.0031 & $1.0[14]$ \\
\hline 3 & $\mathrm{Zn}$ & 0.300 & 0.0929 & $40[17,18]$ \\
\hline 4 & $\mathrm{Cr}$ & 1.5 & 0.0354 & 0.5 [19] \\
\hline 5 & $\mathrm{Cu}$ & 0.040 & 0.0412 & $10[17,18]$ \\
\hline 6 & $\mathrm{Mg}$ & - & 0.3884 & $350[20,21]$ \\
\hline 7 & $\mathrm{Ni}$ & 0.020 & 0.0315 & $\begin{array}{c}7 \text { (children } \\
1-3 \text { years) } \\
40 \text { (adults } \\
19-70 \text { years) } \\
\text { [22] }\end{array}$ \\
\hline
\end{tabular}

Table 4 shows the levels of the heavy metal intake through the daily consumption of the various animal compartments. The mean daily intakes for lead, cadmium, zinc, chromium, copper, magnesium, and nickel for chicken liver tissues from Dareta were 0.0214, 0.0013, $0.0283,0.0147,0.0058,0.1878$, and $0.0058 \mathrm{mg} / \mathrm{day}$, respectively, with LChD1 having the highest daily intake for $\mathrm{Pb}(0.0460 \mathrm{mg} / \mathrm{day})$. LChD2 had the highest intake for $\mathrm{Cd}$ at $0.0020 \mathrm{mg} /$ day. LChD3 has the maximum intakes for chromium (0.0268 mg/day) and nickel (0.0132 mg/day), 
TABLE 4: Daily intake (mg/day) of heavy metals through consumption of the different animal compartments (tissues).

\begin{tabular}{|c|c|c|c|c|c|c|c|}
\hline Animal tissue & $\mathrm{Pb}$ & $\mathrm{Cd}$ & $\mathrm{Zn}$ & $\mathrm{Cr}$ & $\mathrm{Cu}$ & $\mathrm{Mg}$ & $\mathrm{Ni}$ \\
\hline LChD1 & 0.0460 & 0.0012 & 0.0252 & 0.0202 & 0.0054 & 0.2272 & 0.0051 \\
\hline LChD2 & 0.0158 & 0.0020 & 0.0201 & 0.0145 & 0.0030 & 0.1514 & 0.0105 \\
\hline LChD3 & 0.0043 & 0.0010 & 0.0128 & 0.0268 & 0.0035 & 0.1347 & 0.0132 \\
\hline LChD4 & 0.0043 & 0.0016 & 0.0361 & 0.0123 & 0.0061 & 0.2170 & 0.0093 \\
\hline LChD5 & 0.0345 & 0.0004 & 0.0181 & 0.0159 & 0.0082 & 0.1236 & 0.0027 \\
\hline LChD6 & 0.0144 & 0.0020 & 0.0573 & 0.0065 & 0.0074 & 0.2469 & 0.0000 \\
\hline LChD7 & 0.0302 & 0.0012 & 0.0286 & 0.0065 & 0.0072 & 0.2137 & 0.0000 \\
\hline LCAb8 & 0.0144 & 0.0000 & 0.0151 & 0.0202 & 0.0087 & 0.1588 & 0.0267 \\
\hline LCAb9 & 0.0317 & 0.0031 & 0.0155 & 0.0130 & 0.0264 & 0.1279 & 0.0315 \\
\hline LCAb10 & 0.0058 & 0.0010 & 0.0079 & 0.0210 & 0.0050 & 0.1476 & 0.0102 \\
\hline LCAb11 & 0.0158 & 0.0007 & 0.0354 & 0.0181 & 0.0167 & 0.1730 & 0.0072 \\
\hline LCAb12 & 0.0245 & 0.0024 & 0.0213 & 0.0231 & 0.0412 & 0.1485 & 0.0216 \\
\hline LCAb13 & 0.0058 & 0.0014 & 0.0490 & 0.0130 & 0.0212 & 0.1553 & 0.0087 \\
\hline KChD14 & 0.0259 & 0.0017 & 0.0175 & 0.0354 & 0.0063 & 0.1505 & 0.0123 \\
\hline MChD 15 & 0.0417 & 0.0020 & 0.0118 & 0.0217 & 0.0039 & 0.1433 & 0.0063 \\
\hline BMChD 16 & 0.0662 & 0.0007 & 0.0516 & 0.0000 & 0.0067 & 0.3591 & 0.0042 \\
\hline BMChD 17 & 0.1626 & 0.0020 & 0.0929 & 0.0000 & 0.0052 & 0.3315 & 0.0246 \\
\hline LgChD 18 & 0.0043 & 0.0010 & 0.0128 & 0.0268 & 0.0035 & 0.1347 & 0.0105 \\
\hline LgChD 19 & 0.0446 & 0.0016 & 0.0361 & 0.0123 & 0.0061 & 0.2170 & 0.0132 \\
\hline IChD 20 & 0.0202 & 0.0002 & 0.0182 & 0.0289 & 0.0074 & 0.1473 & 0.0105 \\
\hline IChD 21 & 0.0043 & 0.0008 & 0.0139 & 0.0231 & 0.0358 & 0.1797 & 0.0087 \\
\hline BChD 22 & 0.0432 & 0.0021 & 0.0264 & 0.0354 & 0.0282 & 0.3884 & 0.0168 \\
\hline BChD 23 & 0.0576 & 0.0022 & 0.0149 & 0.0202 & 0.0260 & 0.1176 & 0.0147 \\
\hline
\end{tabular}

L: liver tissue; C: cattle; Ch: chicken; D: Dareta; Ab: Abattoir; K: kidney; M: muscle; BM: bone-muscle; Lg: lung; I: intestine; B: brain.

while the highest intakes for $\mathrm{Zn}$ and $\mathrm{Mg}$ were seen in LChD6. LChD5 had the highest daily intake for $\mathrm{Cu}$ at $0.0082 \mathrm{mg} /$ day. For cattle liver tissues from Abattoir, LCAb9 had the maximum daily intake for lead $(0.0317 \mathrm{mg} /$ day $)$, cadmium $(0.0031 \mathrm{mg} /$ day $)$, and nickel $(0.0315 \mathrm{mg} /$ day $)$. LCAb13 the highest intake for zinc $(0.0490 \mathrm{mg} /$ day $)$, LCAb12 had the maximum intake for chromium $(0.0231 \mathrm{mg} /$ day $)$ and copper $(0.0412 \mathrm{mg} /$ day $)$, and LCAb11 had the highest intake for magnesium $(0.1730 \mathrm{mg} /$ day $)$. The mean daily intakes for $\mathrm{Pb}, \mathrm{Cd}, \mathrm{Zn}, \mathrm{Cr}, \mathrm{Cu}, \mathrm{Mg}$, and $\mathrm{Ni}$ if cattle liver tissues from Abattoir are consumed were 0.0163, 0.0014, 0.0240, $0.0181,0.0199,0.1519$, and $0.0177 \mathrm{mg} /$ day, respectively. The daily intake rate for chicken kidney from Dareta was $\mathrm{Pb}$ (0.0259 mg/day), Cd (0.0017 mg/day), Zn (0.0175 mg/day), $\mathrm{Cr}$ (0.0354 mg/day), $\mathrm{Cu}(0.0063 \mathrm{mg} /$ day $), \mathrm{Mg}(0.1505 \mathrm{mg} /$ day $)$, and $\mathrm{Ni}(0.0123 \mathrm{mg} /$ day $)$, while that for chicken muscle was $\mathrm{Pb}(0.0417 \mathrm{mg} /$ day $), \mathrm{Cd}(0.002 \mathrm{mg} /$ day $), \mathrm{Zn}(0.0118 \mathrm{mg} /$ day $)$, $\mathrm{Cr}(0.0271 \mathrm{mg} /$ day $), \mathrm{Cu}(0.0039 \mathrm{mg} /$ day $), \mathrm{Mg}(0.1433 \mathrm{mg} /$ day $)$, and $\mathrm{Ni}(0.0063 \mathrm{mg} /$ day $)$. The mean $\mathrm{Pb}$ daily intakes for chicken bone-muscle, lungs, intestine, and brain from Dareta were $0.1144,0.0245,0.0123$, and $0.0504 \mathrm{mg} /$ day, respectively. For Cd, the mean daily intakes were $0.0014,0.0013,0.0005$, and $0.0022 \mathrm{mg} /$ day, respectively, while for $\mathrm{Zn}$, they were $0.0723,0.0245,0.0161$, and $0.0207 \mathrm{mg} /$ day, respectively. $\mathrm{Cu}$ had mean daily intakes of $0.0060,0.0048,0.0216$, and $0.0271 \mathrm{mg} /$ day, respectively, and $\mathrm{Mg} 0.3453,0.1759,0.1635$, and $0.2530 \mathrm{mg} /$ day, respectively. The average daily intakes for $\mathrm{Ni}$ were $0.0144,0.0129,0.0096$, and $0.0158 \mathrm{mg} / \mathrm{day}$, respectively. Since the concentrations of $\mathrm{Cr}$ in both chicken bone-muscle samples from Dareta were $0.001 \mathrm{mg} / \mathrm{kg}$, the daily intake is negligible. For chicken lungs, intestine, and brain from Dareta, the average daily intake for Cr were 0.0196 , 0.0260 , and 0.0278 , respectively.

The target hazard quotient (THQ) and total target hazard quotient (TTHQ) calculations were used to assess the potential health risk in the consumption of the different animal tissues. These THQs were calculated using the oral reference doses $(\mathrm{mg} / \mathrm{kg} /$ day $)\left(\mathrm{Cr}-1.5 ; \mathrm{Ni}-2.0 \times 10^{-2} ; \mathrm{Pb}-4.0 \times 10^{-3}\right.$; $\left.\mathrm{Cd}-1.0 \times 10^{-3} ; \mathrm{Cu}-4.0 \times 10^{-2} ; \mathrm{Zn}-3.0 \times 10^{-1}\right)$ of the individual metal as stipulated by USEPA (USEPA, IRIS, 1997, 2007). The THQ and TTHQ for all the metals were all below 1.0 (table not shown).

The metal levels in blood and liver showed significant correlation, while $\mathrm{Cd}$ and $\mathrm{Cu}$ showed a negative correlation. There were significant correlations in $\mathrm{Mg}$ and $\mathrm{Ni}(r=0.7983$ and 0.6143 , resp.) in blood and kidney, bone-muscle, muscle, lung, intestine, and brain. Lead, chromium, and copper were found to be negatively correlated. Chromium, cadmium, and copper were strongly correlated $(r=0.7845,0.6879$, and 0.9058 , resp.). Only chromium and zinc showed weak correlation in water and grass samples.

Figure 2 shows the different concentrations of the heavy metals lead, cadmium, zinc, chromium, copper, cobalt, magnesium, and nickel in the liver tissues of chickens and 


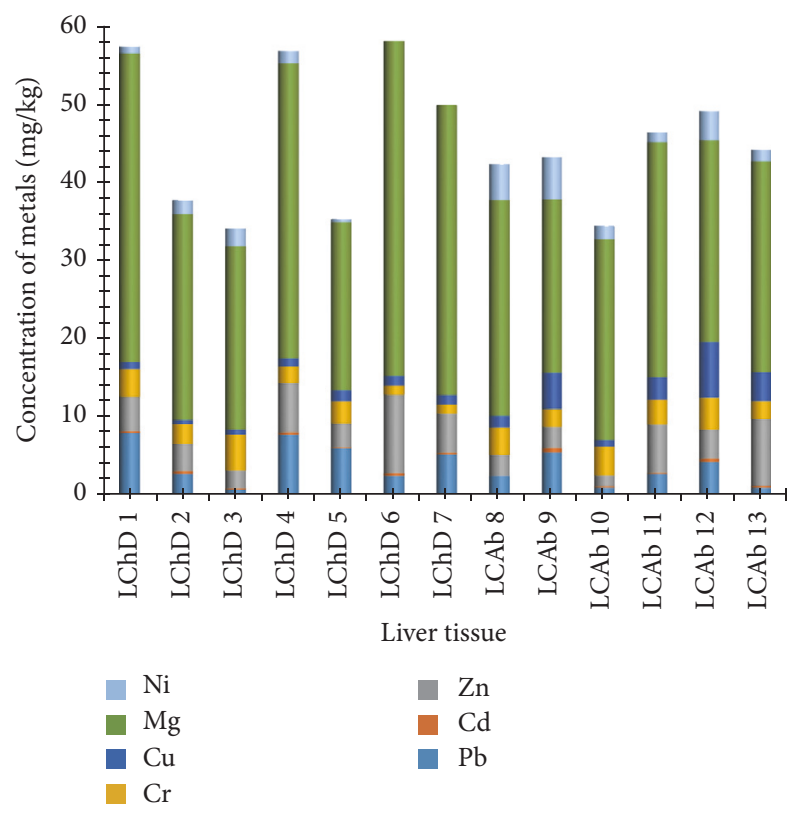

FIGURE 2: The levels (mg/kg) of heavy metals in liver tissues (chicken and cattle) from Dareta and Abattoir. L: liver tissue; C: cattle; Ch: chicken; D: Dareta; Ab: Abattoir.

cattle. Liver tissues of chickens from Dareta had the highest amounts of lead, zinc, chromium, and magnesium (8.0050, $9.9700,4.6550$, and $42.9350 \mathrm{mg} / \mathrm{kg}$, resp.), while cattle from Abattoir had the highest levels of both copper and nickel (7.1600 and $5.4700 \mathrm{mg} / \mathrm{kg}$, resp.). The average levels of lead, cadmium, zinc, chromium, copper, magnesium, and nickel in chicken liver tissues from Dareta are 4.7171, 0.2336, $4.9229,2.5507,1.0121,32.6586$, and $1.0121 \mathrm{mg} / \mathrm{kg}$, respectively, while the mean concentrations of the respective metals in cattle liver tissues from Abattoir are 2.8350, 0.2500, 4.1792, $3.1450,3.4533,26.4067$, and $3.0642 \mathrm{mg} / \mathrm{kg}$. Magnesium was the highest in all liver samples. Other metals had varying concentrations in the samples, with sample LCAb8 showing a negligible level of cadmium. The levels of nickel in samples LChD6 and LCHD7 were also negligible.

Figure 3 shows the different concentrations of the heavy metals lead, cadmium, zinc, chromium, copper, magnesium, and nickel in the kidney, muscle, bone-muscle, lung, intestine, and brain tissues. Chicken bone-muscles from Dareta had the highest concentrations of lead, zinc, and nickel $(28.2750,16.1650$, and $4.2700 \mathrm{mg} / \mathrm{kg}$, resp.), while chicken brain tissues had the highest levels of cadmium, magnesium $(0.3800$ and $67.5400 \mathrm{mg} / \mathrm{kg})$, and chromium $(6.1650 \mathrm{mg} / \mathrm{kg}$, kidney tissue inclusive). The intestine had the most elevated copper level $(6.2250 \mathrm{mg} / \mathrm{kg})$. BMChD4 had the highest cumulative concentration of the heavy metals, followed by samples BChD9 and BMChD3, respectively. Sample LgChD5 had the lowest cumulative level of the heavy metals. The levels of magnesium were seen to be high in all organ-tissue samples.

The metal pollution index in vegetables is shown in Figure 4. Lead and nickel exceeded the metal pollution of one while the MPI of cadmium was also high.

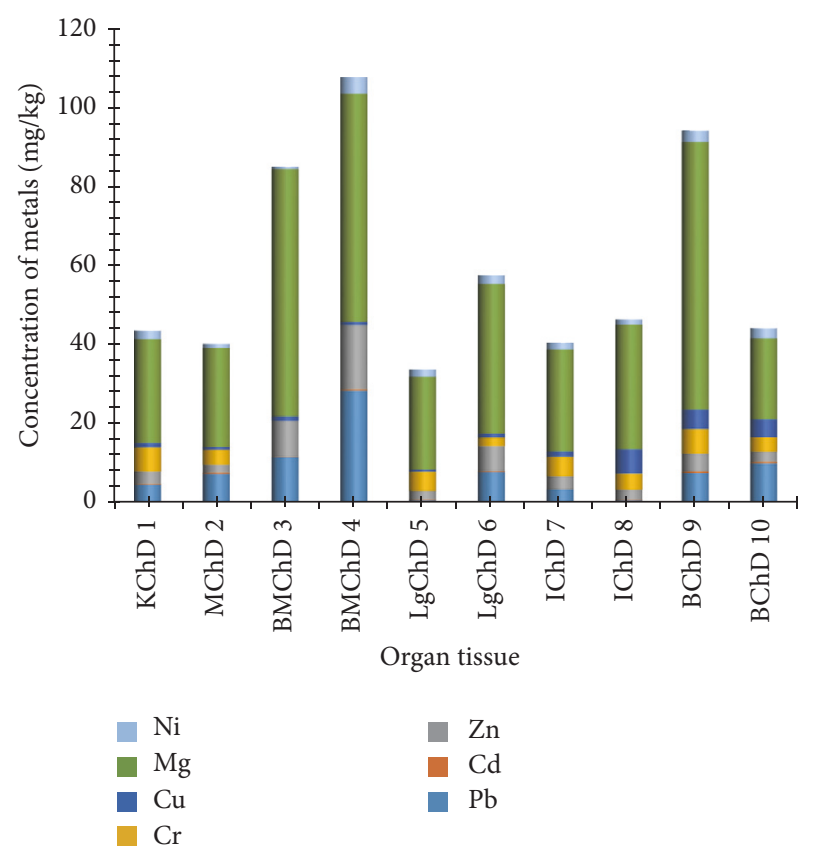

Figure 3: The levels $(\mathrm{mg} / \mathrm{kg})$ of heavy metals in kidney, muscle, bone-muscle, lung, intestine, and brain tissues in chicken from Dareta. K: kidney; M: muscle; BM: bone-muscle; Lg: lung; I: intestine; B: brain; Ch: chicken; D: Dareta.

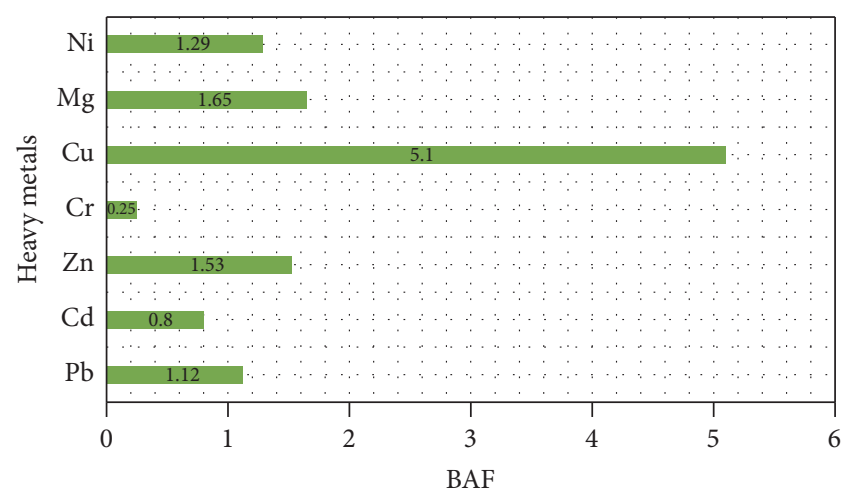

FIGURE 4: Bioaccumulation factor in vegetables.

\section{Discussion}

Artisanal mining is an essential activity in many developing countries as it provides an important source of livelihood, particularly in regions where economic alternatives are limited. Unfortunately, these activities are frequently accompanied by extensive environmental degradation and deplorable social conditions, both during operations and well after mining activities have ceased. Potential toxic metals are natural components of the environment, but human activities, notably industrial mining processes, have been responsible for the wider distribution of these elements. Mining and processing metal ore can be a significant source of heavy metal contamination of the environment [29]. The environmental concern in mining areas is primarily related to physical disturbance of the surrounding landscape, spilled 
mine tailings, emitted dust, and acid mine drainage transported into rivers. Excessive accumulation of heavy metals in agricultural soils around mining areas, resulting in elevated heavy metal uptake by food crops, is of great concern because of potential health risk to the local inhabitants [30]. The consumption of foods produced in contaminated areas and the ingestion or inhalation of contaminated particles are two principal exposure pathways of these potential toxic metals in man. Potential health risks to humans and animals from consumption of crops can be due to heavy metal uptake from contaminated soils via plant roots as well as direct deposition of contaminants from the atmosphere onto plant surfaces [31]. Food contamination by heavy metals depends on both their mobility in the soil and their bioavailability. Though some of the mobility and bioavailability factors are easy to measure, determination of the food risk contamination is tricky. The lead and cadmium levels in soil and vegetable from Dareta are higher than the values reported by [32]. Lead and cadmium levels in vegetables grown in irrigated farmland of Kaduna metropolis have been reported to be $0.92-4.67 \mu \mathrm{g} \mathrm{Pb} / \mathrm{g}$ and $0.1-1.3 \mu \mathrm{g} \mathrm{Cd} / \mathrm{g}$ [32]. Consumption of the vegetables from this region may constitute health hazard to humans since these metals' levels were above FAO/WHO alimentarium standard. Metal pollution index (MPI) was calculated in this study to determine the metal pollution monitoring in soil and vegetable. The impact of heavy metal pollution on different matrices depends on the bioaccumulation of the individual metals which are toxic at high concentrations. Pollution index calculates the relative contamination of different metals separately and manifests the sum of generated components as a representative [33]. A heavy metal pollution index value of $>1$ indicates pollution, whereas MPI value of $<1$ indicates no pollution [34]. The MPI values of lead, nickel, and cadmium, which were all $<1$ in the vegetable, are an evidence of significant contamination of both human and veterinary public health importance.

Although the THQ and TTHQ for all the metals were all below 1.0, suggesting no metallotoxicity from the ingestion of these meat, vegetables, and drinking water from Zamfara State artisanal mining communities, potential chronic toxicity is of concern given the fact that some of the metals exceeded the maximum allowable limits in foods. The accumulation of cadmium, copper, magnesium, and nickel in the liver of goat, sheep, cattle, and chicken may be independent of their blood levels as suggested by their poor correlation. The significant correlation in $\mathrm{Mg}$ and $\mathrm{Ni}(r=0.7983$ and 0.6143 , resp.) in blood and kidney, bone-muscle, muscle, lung, intestine, and brain suggests that increases in the blood levels of $\mathrm{Mg}$ and $\mathrm{Ni}$ may have contributed to their accumulation in the kidney, bone-muscle, muscle, lungs, intestine, and brain of the animals. Similarly, the soil sample concentrations of cadmium, chromium, and copper may have contributed to the accumulation of these metals in the vegetable samples as suggested by their strong correlation. The contamination of soils with toxic environmental contaminants is a pervasive problem of potential human health concern to those individuals working and residing near hazardous waste sites. Soil contamination may directly impact human health through the following exposure pathways: incidental ingestion of surface soil, particularly by children who may gain access to the site or by on-site workers exhibiting frequent handto-mouth activity (e.g., smokers); and direct dermal contact and inhalation of contaminated fugitive dust by workers and nearby residents during remedial activities or inclement weather conditions. In addition, soil contamination may adversely impact human health by contributing to groundwater and surface water contamination by means of infiltration and surface runoff, respectively. Artisanal mining activity from the present study tended to have negligible impact of the levels of lead, cadmium, zinc, chromium, and copper in the drinking water. Drinking water might not be a major source of metal pollution in Zamfara.

The potential toxic metals, lead, cadmium, nickel, zinc, chromium, and copper, are, respectively, classified as numbers $2,7,57,75,78$, and 118 on the priority list of the most hazardous substances in the environment by the Agency for Toxic Substances and Diseases Registry [35]. Some metals such as cadmium are mobile in plants and may become concentrated in leaves. Grazing animals may potentially be highly exposed to these elements via ingestion of polluted soil, vegetation, and drinking water and possibly also via inhalation [36, 37]. Knowledge of metal concentrations in livestock is therefore important for assessing the effects of these pollutants on domestic animals, as well as the potential risk from human consumption.

Lead poisoning is more common in farm ruminants [38]. In ruminants blood lead level up to $0.25 \mu \mathrm{g} / \mathrm{mL}$ is considered safe; however, BLL above $0.35 \mu \mathrm{g} / \mathrm{mL}$ is toxic [39]. The higher BLLs seen in goats, sheep, and cattle reared around these mining sites may be mainly due to ingestion of pasture contaminated with lead as well as inhalation of lead particles [40]. Lead is considered as the most common form of poisoning in farm animals because of natural curiosity, licking habits, and lack of oral discrimination [41]. In this study, BLLs of goat $(2.0000-30.2750 \mathrm{mg} / \mathrm{kg})$ (1.7500-7.2550) in Dareta and Abare, respectively, sheep (3.0000-9.5100 mg/kg), cattle (0.7500-10.7600 mg/kg), and chicken $(0.7500-8.2550 \mathrm{mg} / \mathrm{kg})$ in Dareta, reared in mining sites, were higher than $0.35 \mu \mathrm{g} / \mathrm{mL}$, toxic level reported for ruminants [39]. Chicken meat from Dareta had lead levels ranging from 0.7500 to $28.2750 \mathrm{mg} / \mathrm{kg}$, chromium levels of up to $6.1650 \mathrm{mg} / \mathrm{kg}$, and nickel levels from 0.7300 to $4.2700 \mathrm{mg} / \mathrm{kg}$. Lead levels exceeded the Codex Alimentarius guideline for $\mathrm{Pb}$ in muscles $(0.1 \mathrm{mg} / \mathrm{kg})$ and edible offal $(0.5 \mathrm{mg} / \mathrm{kg})$ of cattle.

In a study of cadmium and lead levels in the muscle and edible offals of cow reared in Nigeria, [42] reported cadmium $(\mathrm{mg} / \mathrm{kg})$ which ranged from $0.01-0.80$ in muscle, $<0.004-0.90$ in liver, $0.10-1.12$ in kidney, $0.01-0.90$ in intestine, and 0.01-1.10 in tripe while the lead was $<0.005-0.72$ in muscle, 0.08-501.79 in liver, 0.04-44.89 in kidney, 0.01-108.02 in intestine, and 0.01-127.90 in tripe. Similarly high cadmium levels in kidney $(0.07-3.08 \mu \mathrm{g} / \mathrm{g})$ and in muscle $(0.09-1.26 \mu \mathrm{g} / \mathrm{g})$ have been reported by [43] in goat meat in Nigeria. Paper [44] reported high lead level $(59.03-88.88 \mu \mathrm{g} / \mathrm{g}$ in liver; muscle $(47.36-147.07 \mu \mathrm{g} / \mathrm{g}))$ and high cadmium level (liver (1.78-8.80), muscle $(6.53-15.32 \mu \mathrm{g} / \mathrm{g})$, and gizzard $(3.78-7.10 \mu \mathrm{g} / \mathrm{g}))$ in local and 
exotic poultry meat. Paper [45] reported mean lead levels $(\mu \mathrm{g} / \mathrm{g}): 66.70 \pm 0.70$ in lungs; $85.20 \pm 0.00$ in liver, and $38.70 \pm$ 0.20 in kidney of cow in Kwara State, Nigeria. Paper [46] reported $\mathrm{Pb}(0.01-4.60 \mathrm{mg} / \mathrm{kg})$ and $\mathrm{Cd}(0.01-5.68 \mathrm{mg} / \mathrm{kg})$ in chicken meat from southern Nigeria. Paper [47] reported high levels of $\mathrm{Pb}(0.80-1.42 \mathrm{mg} / \mathrm{kg}), \mathrm{Cd}(0.28-1.50 \mathrm{mg} / \mathrm{kg})$, $\mathrm{Pb}(0.02-1.36 \mathrm{mg} / \mathrm{kg})$, and $\mathrm{Cd}(0.04-0.93 \mathrm{mg} / \mathrm{kg})$ in cow and goat meat parts, respectively. In all, different anthropogenic activities ranging from burning of fossil fuel, vehicular traffic, and so forth were attributed as likely sources of these metals.

The high potential toxic metal levels in these meat samples must have been due to the artisanal mining activities. The presence of high levels of potential toxic metals in all the meat samples in this study is of grave public health importance.

Blood cadmium level in chicken from Dareta was the highest. Cadmium levels in some of the meat samples exceeded the EU set limit of $0.05 \mathrm{mg} / \mathrm{kg}$ for Cd in meat.

The mean cadmium levels in the goat, sheep, cattle, and chicken meat parts from the contaminated areas of Zamfara State are higher than $0.161 \mathrm{mg} / \mathrm{kg}$ reported by Miranda and coworkers in 2005 in cattle from polluted industrialised communities of Spain. From many polluted areas around Europe, different meat cadmium levels have been documented, namely, $0.038 \mathrm{mg} / \mathrm{kg}$ [48] of meat from polluted area in Poland; $0.021 \mathrm{mg} / \mathrm{kg}$ [49] in Finland; $0.053 \mathrm{mg} / \mathrm{kg}$ [50] in Hungary; and $0.0985 \mathrm{mg} / \mathrm{kg}$ [51] in Eastern Slovakia. Taken together, the mean meat cadmium levels from Zamfara in this study were higher than the European values but were however lower than $1.6 \mathrm{mg} / \mathrm{kg}$ (fresh weight) that Garco-Rico and coworkers [52] reported in swine kidney from Sonora. Cadmium has a long biological half-life of about 30 years in humans [53]. It damages the proximal tubules of nephron, leading first to proteinuria and essential ions like calcium into the urine which may progress to renal failure [54]. Cadmium has been shown to be toxic to human populations from occupational inhalation exposure and accidental ingestion of cadmium-contaminated food. Inhalation of cadmium dust in certain occupational settings may be associated with an increased incidence of lung cancer. Other symptoms include irritation of upper respiratory tract, metallic taste in the mouth, cough, and chest pains $[55,56]$. Cadmium is poorly absorbed from the lung, gastrointestinal tract, and skin. Individuals with dietary deficiencies of iron, calcium, or protein exhibit higher absorption of ingested cadmium. Cadmium in the body binds readily to certain sulphur-containing proteins, such as metallothionein. Binding to metallothionein is thought to reduce the toxicity of cadmium. Following ingestion, faecal excretion is high due to poor gastrointestinal absorption. Most cadmium that has been absorbed, however, is excreted very slowly, with faecal and urinary excretion being about equal. Urinary cadmium levels are an indicator of body burden. Experimental studies and epidemiological surveys have linked cadmium exposure with many types of cancer such as lung, prostate, renal, liver, hematopoietic system, urinary bladder, pancreatic, testis, and stomach cancers [57-59]. Exposure to cadmium can also affect the function of the nervous system [60,61], with symptoms including headache and vertigo, olfactory dysfunction, Parkinsonian-like symptoms, slowing of vasomotor functioning, peripheral neuropathy, decreased equilibrium, decreased ability to concentrate, and learning disabilities $[62,63]$.

Copper is a trace element needed in the body for various biochemical processes with permissible limits of $20 \mathrm{mg}$ /day and a lethal dose limit of $100 \mathrm{mg} /$ day. The amount of copper in most food is usually about 5 to $7 \mathrm{mg} / \mathrm{kg}$; therefore, cases of copper poisoning are rarely reported [64]. The maximum levels of the estimated daily intake of all the metals in the analysed meat samples were all below their respective permissible limits or upper tolerable limits as stipulated by the various authorities. Copper and zinc levels were low in all the goat, sheep, cattle, and chicken parts including muscles in this study. Muscle is one of the important tissues for zinc accumulation and possesses zinc concentrations that were similar to those in the liver [65]. The Cd/Zn ratios in goat, sheep, and chicken meat from Dareta, the most polluted community, were $0.16,0.15,0.43$, and 0.46 , respectively. Thus, the low zinc concentration in the different meat samples may be attributed to higher cadmium accumulation in these meat samples. The high levels of the potential toxic metals including cadmium in the goat, sheep, cattle, and chicken parts from the artisanal mining areas of Zamfara State, Nigeria, tended to impair the meat quality. According to $[66,67]$, cadmium causes reductions in both intestinal zinc absorption and hepatic zinc reserves in cattle, respectively, as a result of competition for the cation-binding sites of metallothionein (MT).

The highest estimated daily intake of nickel in this study was 0.0315 (mg/kg bw day). The World Health Organization (WHO) tolerable daily intake (TDI) of nickel is $5 \mu \mathrm{g} / \mathrm{kg} \mathrm{bw}$ day. Higher dietary nickel contributions, ranging from 200 to $900 \mu \mathrm{g}$ day-1, have been reported $[68,69]$. The dietary intake of nickel does not lead to any health risk in the general population but could be of public health concern in some sensitized individuals [70]. The lung has been identified as the critical target of nickel toxicity. Nickel substitution for other essential elements may contribute to the adverse health effects of nickel. Nickel can replace magnesium in certain steps in the activation of complement [71]. The replacement of nickel for magnesium leads to a 40 -fold increase in the formation of $\mathrm{C} 3 \mathrm{~b}, \mathrm{Bb}$ enzyme, which amplifies activation of the complement pathway.

Concurrent exposure to heavy metal mixtures near mining sites is well known and environmental health issues in developing nations are more often exacerbated by socioeconomic and political instabilities. The scenario of increasing chemical disease combined with morbidity due to communicable disease exacerbates the already beleaguered public health problems of developing nations [72]. As the incidence of hazardous waste sites, pesticide and pharmaceutical production, manufacturing enterprises, and mining become more prevalent in developing countries, environmental health crises will increasingly contribute to environmental and public health burden. Small-scale mining grew by $20 \%$ in a five-year period in 35 countries across Africa, Asia, and Latin America [73]. Studies of toxicological 
interactions of chemical mixtures predominantly focus on pairs of xenobiotics [74]. Yet the relevance of multiple toxicant exposures is critical in global public health. The present study has therefore shown that lead may not be the only toxic metal of public health concern in the contaminated mining communities of Dareta, Abare, and Gusau of Zamfara State given the high levels of cadmium in meat and vegetables samples from these areas. In view of the nonbiodegradable and persistent nature of heavy metals and the longterm low dose exposure of the population to these heavy metals, the associated health hazards should be investigated to understand the size of the problem. To prevent health risks, government and relevant regulatory agencies should adopt more stringent measures to reduce and monitor heavy metal contamination of soil and agricultural produce and livestock [75]. Mining activities which ceased decades or even centuries ago but worked under the absence of environmental health regulations constitute significant source of contamination and environmental risk [75]. Since there is a marked risk of lead poisoning in younger animals and in cattle herds [76], further studies are imperative to understand the combined impact of these metals especially lead and cadmium in both livestock and man. As a consequence, land remediation and/or alternative management practices are required in these mining communities to reduce the impact of artisanal gold mining activities.

\section{Conflicts of Interest}

The authors declare that there are no conflicts of interest regarding the publication of this paper.

\section{Authors' Contributions}

O. E. Orisakwe designed and analysed data and write-up; O. O. Oladipo contributed to the design and field work; G. C. Ajaezi and N. A. Udowelle analysed the data and contributed to write-up.

\section{Acknowledgments}

This work was funded by the researchers.

\section{References}

[1] TerraGraphics, "UNICEF programme cooperation agreement: environmental remediation-lead poisoning in Zamfara, Moscow," UNICEF: Final Report, 2011.

[2] O. E. Orisakwe, J. K. Nduka, C. N. Amadi, D. O. Dike, and O. Bede, "Heavy metals health risk assessment for population via consumption of food crops and fruits in Owerri, South Eastern, Nigeria," Chemistry Central Journal, vol. 6, article 77, 2012.

[3] Agency for Toxic Substances and Disease Registry, Toxicological Profile for Lead, US Department of Health and Human Services, Agency for Toxic Substances and Disease Registry, Atlanta, Ga, USA, 2007.

[4] L. Hubbs-Tait, J. R. Nation, N. F. Krebs, and D. C. Bellinger, "Neurotoxicants, micronutrients, and social environments individual and combined effects on children's development," Psychological Science in the Public Interest, Supplement, vol. 6, no. 3, pp. 57-121, 2005.
[5] ATSDR Agency for Toxic Substances and Disease Registry, Toxicological Profile for Cadmium, Agency for Toxic Substances Disease Registry, Atlanta, Ga, USA, 2008.

[6] Agency for toxic substances and disease registry, 2005, pp. 1-397.

[7] L. R. McDowell, Minerals in Animal and Human Nutrition, Elsevier Science, Amsterdam, The Netherlands, 2nd edition, 2003.

[8] C. L. Broadhurst and P. Domenico, "Clinical studies on chromium picolinate supplementation in diabetes mellitus-A review," Diabetes Technology and Therapeutics, vol. 8, no. 6, pp. 677-687, 2006

[9] D. G. Barceloux, "Chromium," Journal of Toxicology: Clinical Toxicology, vol. 37, no. 2, pp. 173-194, 1999.

[10] D. G. Barceloux, "Cobalt," Journal of Toxicology: Clinical Toxicology, vol. 37, no. 2, pp. 201-216, 1999.

[11] D. G. Barceloux, “Copper," Journal of Toxicology: Clinical Toxicology, vol. 37, no. 2, pp. 217-230, 1990.

[12] Y.-C. Lo, C. A. Dooyema, A. Neri et al., "Childhood lead poisoning associated with gold ore processing: a villagelevel investigation-Zamfara State, Nigeria, October-November 2010," Environmental Health Perspectives, vol. 120, no. 10, pp. 1450-1455, 2012.

[13] USEPA, "Integrated risk information system-database," Philadelphia, Pa, USA, 2007.

[14] EC, "Commission regulation no. 466/2001 of 8 March 2001," Official Journal of European Communities, vol. 1, no. 77, 1 page.

[15] FAO, "Compilation of legal limits for hazardous substance in fish and fishery products (Food and Agricultural Organization)," FAO Fishery Circular 464, 1983.

[16] JECFA, "Evaluation of certain contaminants in food: fifth session of the joint FAO/WHO food standards programme codex committee on contaminants in foods," Codex Alimentarius Commission CF/5 INF/1, 2011, http://www.fao.org/ input/download/report/758/REP11_CFe.pdf.

[17] Food and Drug Administration, "Dietary reference intakes for vitamin A, vitamin K, Arsenic, Boron, Chromium, Copper, Iodine, Iron, Manganese, Molybdenum, Nickel, Silicon, Vanadium, and Zinc," Report of the Panel on Micronutrients, National Academy Press, Washington, DC, USA, 2001, Food and Drug Administration, Dietary supplements, Center for Food Safety and Applied Nutrition.

[18] Institute of Medicine (IOM), FNB. Dietary Reference Intakes for Vitamin A, Vitamin K, Arsenic, Boron, Chromium, Copper, Iodine, Iron, Manganese, Molybdenum, Nickel, Silicon, Vanadium and Zinc, National Academy Press, Washington, DC, USA, 2001.

[19] L. Piskorova, Z. Vasilkova, and I. Krupicer, "Heavy metal residues in tissues of wild boar (Susscrofa) and red fox (Vulpesvulpes) in the central Zemplin region of the Slovak Republic," Czech Journal of Animal Science, vol. 48, pp. 134-138, 2003.

[20] Health Canada, Dietary Reference Intakes Table, Health Canada, Canada, http://www.hc-sc.gc.ca/fn-an/nutrition/reference/ table/index-eng.php.

[21] Institute of Medicine (IOM) and Food and Nutrition Board (FNB), Dietary Reference Intakes for Calcium, Phosphorus, Magnesium, Vitamin D and Fluoride, National Academy Press, Washington, DC, USA, 1999.

[22] Institute of Medicine (IOM), Dietary Reference Intakes: Applications in Dietary Planning. Sub Committee on Interpretation 
And Uses of Dietary Reference Intakes And The Standing Committee on The Scientific Evaluation of Dietary Reference Intakes, Institute of Medicine of the National Academies, The National Academies Press, Washington, DC, USA, 2003.

[23] P. Zhuang, M. B. McBride, H. Xia, N. Li, and Z. Li, "Health risk from heavy metals via consumption of food crops in the vicinity of Dabaoshan mine, South China," Science of the Total Environment, vol. 407, no. 5, pp. 1551-1561, 2009.

[24] K. Y. Ge, The Status of Nutrient and Meal of Chinese in The 1990s, Beijing People's Hyg.Press, Beijing, China, 1992.

[25] X. Wang, T. Sato, B. Xing, and S. Tao, "Health risks of heavy metals to the general public in Tianjin, China via consumption of vegetables and fish," Science of the Total Environment, vol. 350, no. 1-3, pp. 28-37, 2005.

[26] USEPA, "Office of water regulations and standard: guidance manual for assessing human health risks from chemically contaminated, fish and shellfish," Tech. Rep. EPA-503/8-89-002, U.S. Environmental Protection Agency, Washington, DC, USA, 1989.

[27] L.-C. Chien, T.-C. Hung, K.-Y. Choang et al., "Daily intake of TBT, Cu, Zn, Cd and As for fishermen in Taiwan," Science of the Total Environment, vol. 285, no. 1-3, pp. 177-185, 2002.

[28] D. H. Bennett, W. E. Kastenberg, and T. E. McKone, "A multimedia, multiple pathway risk assessment of atrazine: The impact of age differentiated exposure including joint uncertainty and variability," Reliability Engineering and System Safety, vol. 63, no. 2, pp. 185-198, 1999.

[29] M. C. Navarro, C. Perez-Sirvent, M. J. Martinez-Sanchez, J. Vidal, P. J. Tovar, and J. Bech, "Abandoned mine sites as a source of contamination by heavy metals: a case study in a semi-arid zone," Journal of Geochemical Exploration, vol. 96, pp. 186-193, 2008.

[30] C. Pruvot, F. Douay, F. Hervé, and C. Waterlot, "Heavy metals in soil, crops and grass as a source of human exposure in the former mining areas," Journal of Soils and Sediments, vol. 6, no. 4, pp. 215-220, 2006.

[31] M. Miranda, M. López-Alonso, C. Castillo, J. Hernández, and J. L. Benedito, "Effects of moderate pollution on toxic and trace metal levels in calves from a polluted area of northern Spain," Environment International, vol. 31, no. 4, pp. 543-548, 2005.

[32] W. L. O. Jimoh and I. M. Mohammed, "Assessment of cadmium and lead in soils and tomatoes grown in irrigated farmland in the Kaduna metropolis Nigeria," Research Journal of Environmental and Earth Sciences, vol. 4, no. 1, pp. 55-59, 2012.

[33] B. Backman, D. Bodiš, P. Lahermo, S. Rapant, and T. Tarvainen, "Application of a groundwater contamination index in Finland and Slovakia," Environmental Geology, vol. 36, no. 1-2, pp. 5564, 1998.

[34] B. R. R. Seshan, U. Natesan, and K. Deepthi, "Geochemical and statistical approach for evaluation of heavy metal pollution in core sediments in southeast coast of India," International Journal of Environmental Science and Technology, vol. 7, no. 2, pp. 291-306, 2010.

[35] ATSDR, The 2011 Priority List of Hazardous Substances, Agency for Toxic Substances and Disease Registry, Atlanta, Ga, USA, 2011, http://www.atsdr.cdc.gov/SPL/index.html.

[36] P. Madejón, M. T. Dominguez, and J. M. Murillo, "Evaluation of pastures for horses grazing on soils polluted by trace elements," Ecotoxicology, vol. 18, pp. 417-428, 2009.

[37] M. M. Reglero, L. Monsalve-González, M. A. Taggart, and R. Mateo, "Transfer of metals to plants and red deer in an old lead mining area in Spain," Science of the Total Environment, vol. 406, no. 1-2, pp. 287-297, 2008.

[38] M. R. Aslani, M. Heidarpour, V. Najarnezhad, M. Mostafavi, and Y. Toosi- zadeh-Khorasani, "Lead poisoning in cattle associated with batteries recycling: high lead levels in milk of non-symptomatic exposed cattle," Iranian Journal of Veterinary Science and Technolog, vol. 4, pp. 47-52, 2012.

[39] O. M. Radostitis, D. C. Blood, C. C. Gay, and H. E. Hinchcliff, Veterinary Medicine: A Text Book of Disease of Cattle, Sheep, Pigs, Goats and Horses, WB Saunders, London, UK, 2000.

[40] I. A. Okada, A. M. Sakuma, F. D. Maio, S. Dovidauskas, and O. Zenebon, "Evaluation of lead and cadmium levels in milk due to environmental contamination in the Paraiba Valley region of Southeastern Brazil," Revista de Saude Publica, vol. 31, no. 2, pp. 140-143, 1997.

[41] O. M. Radostitis, C. C. Gay, K. W. Hinchcliff, and P. D. Constable, Veterinary Medicine, W.B. Saunders, London, UK, 10th edition, 2007.

[42] J. N. Ihedioha and C. O. B. Okoye, "Cadmium and lead levels in muscle and edible offal of cow reared in Nigeria," Bulletin of Environmental Contamination and Toxicology, vol. 88, no. 3, pp. 422-427, 2012.

[43] C. O. B. Okoye and J. N. Ugwu, "Impact of environmental cadmium, lead, copper and zinc on quality of goat meat in Nigeria," Bulletin of the Chemical Society of Ethiopia, vol. 24, no. 1, pp. 133-138, 2010.

[44] C. O. B. Okoye, A. U. Aneke, C. N. Ibeto, and J. N. Ihedioha, "Heavy metals analysis of local and exotic poultry meat," International Journal of Applied Environmental Sciences, vol. 6, no. 1, pp. 49-55, 2011.

[45] G. B. Adebayo, G. A. Otunola, and F. O. Oladipo, "Determination of trace elements in selected organs of cow for safety consumption among rural dwellers in Kwara State, Nigeria," Pakistan Journal of Nutrition, vol. 8, no. 12, pp. 1855-1857, 2009.

[46] C. M. A. Iwegbue, G. E. Nwajei, and E. H. Iyoha, "Heavy metal residues of chicken meat and gizzard and turkey meat consumed in southern Nigeria," Bulgarian Journal of Veterinary Medicine, vol. 11, no. 4, pp. 275-280, 2008.

[47] J. N. Asegbeloyin, A. E. Onyimonyi, O. T. Ujam, N. N. Ukwueze, and P. O. Ukoha, "Assessment of toxic trace metals in selected fish species and parts of domestic animals," Pakistan Journal of Nutrition, vol. 9, no. 3, pp. 213-215, 2010.

[48] J. Falandysz, W. Kotecka, and K. Kurunthachalam, "Mercury, lead, cadmium, manganese, copper, iron and zinc concentrations in poultry, rabbit and sheep from the northern part of Poland," The Science of the Total Environment, vol. 141, p. 51, 1994.

[49] R. Tahvonen, "Contents of lead and cadmium in selected fish species consumed in Finland in 1993-1994," Food Additives and Contaminants, vol. 1, p. 1, 1996.

[50] J. Bokori and S. Fekete, Acta Vet. Hung, vol. 43, no. 3, 1995.

[51] M. Skalická, B. Koréneková, P. Nad, and Makoóvá Z., Veterinarski Archiv, vol. 72, no. 11, 2002.

[52] L. Garco-Rico, C. Frasquillo-Felix, R. Robles-Burgueño, and M. Jara-Marini, "Determination of cadmium and zinc and its relationship to metallothionein levels in swine kidney," Revista Internacional de Contaminación Ambiental, vol. 18, no. 157, 2002.

[53] R. P. Bellies, Patty's Industrial Hygiene and, Toxicology, vol. 2, Part C, 4th, in series (edited by Clayton, G. D.) edition.

[54] S. Satrug, M. R. Haswell-Elkins, and M. R. Moore, Br. J. Nutr, vol. 84, p. 791, 2000. 
[55] E. C. Foulkes, "Absorption of cadmium," in Handbook of Experimental Pharmacology, E. C. Foulkes, Ed., vol. 80, pp. 75100, Springer, Berlin, Germany, 1986.

[56] Z. A. Shaikh and J. C. Smith, "The biosynthesis of metallothionein in rat liver and kidney after administration of cadmium," Chemico-Biological Interactions, vol. 15, no. 4, pp. 327-336, 1976.

[57] M. P. Waalkes, "Cadmium carcinogenesis in review," Journal of Inorganic Biochemistry, vol. 79, no. 1-4, pp. 241-244, 2000.

[58] B. Pesch, J. Haerting, U. Ranft, A. Klimpel, B. Oelschlägel, and W. Schill, "Occupational risk factors for renal cell carcinoma: agent-specific results from a case-control study in Germany: MURC study group: multicenter urothelial and renal cancer study," International Journal of Epidemiology, vol. 29, no. 6, pp. 1014-1024, 2000.

[59] P. Joseph, T. K. Muchnok, M. L. Klishis et al., "Cadmiuminduced cell transformation and tumorigenesis are associated with transcriptional activation of c-fos, c-jun, and c-myc proto-oncogenes: Role of cellular calcium and reactive oxygen species," Toxicological Sciences, vol. 61, no. 2, pp. 295-303, 2001.

[60] E. López, S. Figueroa, M. J. Oset-Gasque, and M. P. González, "Apoptosis and necrosis: two distinct events induced by cadmium in cortical neurons in culture," British Journal of Pharmacology, vol. 138, no. 5, pp. 901-911, 2001.

[61] Y. Cao, A. Chen, J. Radcliffe et al., "Postnatal cadmium exposure, neurodevelopment, and blood pressure in children at 2, 5, and 7 years of age," Environmental Health Perspectives, vol. 117, no. 10, pp. 1580-1586, 2009.

[62] S. D. Kim, C. K. Moon, S.-Y. Eun, P. D. Ryu, and S. A. Jo, "Identification of ASK1, MKK4, JNK, c-Jun, and caspase-3 as a signaling cascade involved in cadmium-induced neuronal cell apoptosis," Biochemical and Biophysical Research Communications, vol. 328, no. 1, pp. 326-334, 2005.

[63] R. K. Monroe and S. W. Halvorsen, "Cadmium blocks receptormediated Jak/STAT signaling in neurons by oxidative stress," Free Radical Biology and Medicine, vol. 41, no. 3, pp. 493-502, 2006.

[64] C. M. A. Iwegbue, "Trace metal contents in some brands of canned beef in Nigeria," Toxicological and Environmental Chemistry, vol. 93, no. 7, pp. 1368-1374, 2011.

[65] M. López-Alonso, J. L. Benedito, M. Miranda, C. Castillo, J. Hernádez, and R. F. Shore, "Arsenic, cadmium, lead. copper and zinc in cattle from Galacia, NW Spain," The Science of the Total Environment, vol. 246, pp. 237-248, 2000.

[66] R. M. Smith, R. M. Leach, L. D. Muller, L. C. Griel, and Baker D. E., "Effects of long-term dietary cadmium chloride on tissue, milk and urine mineral concentrations of lactating dairy cows," Journal of Animal Science, vol. 69, p. 4088, 1991.

[67] R. A. Goyer, “Toxic and essential metal interactions," Annual Review of Nutrition, vol. 17, pp. 37-50, 1997.

[68] D. R. Myron, T. J. Zimmertan, T. R. Shuleu, L. M. Klevay, D. E. Lee, and F. H. Nielson, "Intake of nickel and vanadium by humans: a survey of selected diets," The American Journal of Clinical Nutrition, vol. 33, pp. 527-531, 1978.

[69] E. H. Larsen, N. L. Anderson, A. Moller, A. Peterson, G. K. Mortensen, and J. Peterson, "Monitoring the content and intake of trace element from food in Denmark," Food Additives and Contaminants, vol. 19, no. 1, pp. 33-46, 2002.

[70] A. Duran, M. Tuzen, and M. Soylak, "Trace metal contents in chewing gums and candies marketed in Turkey," Environmental Monitoring and Assessment, vol. 149, no. 1-4, pp. 283-289, 2009.
[71] H. McCoy and M. A. Kenney, "A review of biointeractions of $\mathrm{Ni}$ and $\mathrm{Mg}$ : in immune system and oncology," Magnesium Research, vol. 5, no. 3, pp. 223-232, 1992.

[72] P. J. Landrigan, W. A. Suk, and R. W. Ameir, "Chemical wastes, children's health, and the superfund basic research program," Environmental Health Perspectives, vol. 107, pp. 423-427, 1999.

[73] L. Yanez, D. Ortiz, J. Calderon et al., "Overview of human health and chemical mixtures: problems facing developing countries," Environmental Health Perspectives, vol. 110, pp. 901-909.

[74] R. C. Hertzberg and L. K. Teuschler, "Evaluating quantitative formulas for dose-response assessment of chemical mixtures," Environmental Health Perspectives, vol. 110, no. 6, pp. 965-970, 2002.

[75] H. M. Conesa and Á. Faz, "Metal uptake by spontaneous vegetation in acidic mine tailings from a semiarid area in south Spain: Implications for revegetation and land management," Water, Air, and Soil Pollution, vol. 215, no. 1-4, pp. 221-227, 2011.

[76] J. Rodríguez-Estival, J. A. Barasona, and R. Mateo, “Blood Pb and $\delta$-ALAD inhibition in cattle and sheep from a Pb-polluted mining area," Environmental Pollution, vol. 160, no. 1, pp. 118$124,2012$. 


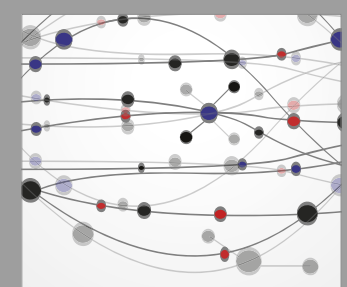

The Scientific World Journal
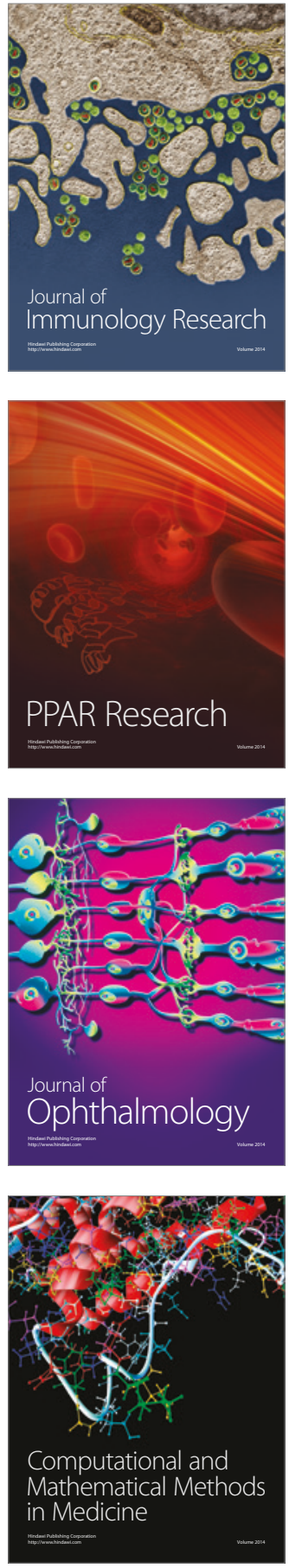

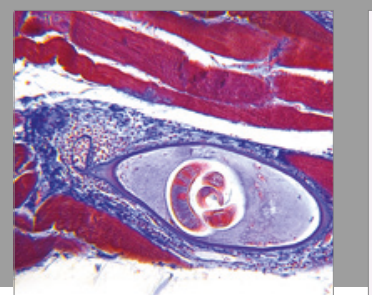

Gastroenterology Research and Practice
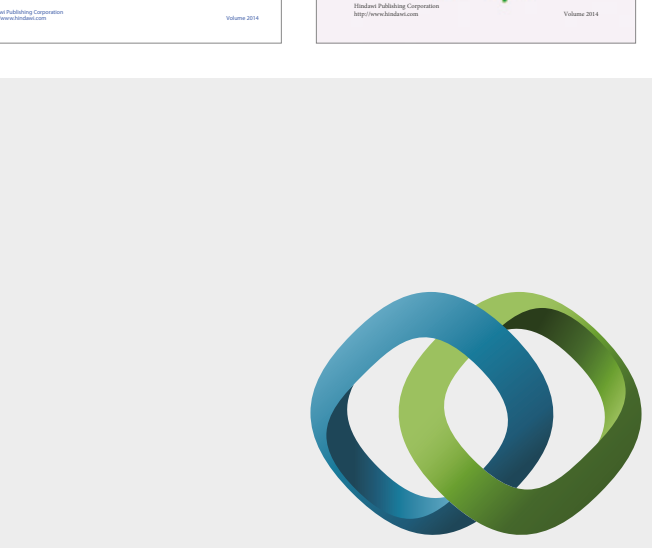

\section{Hindawi}

Submit your manuscripts at

https://www.hindawi.com
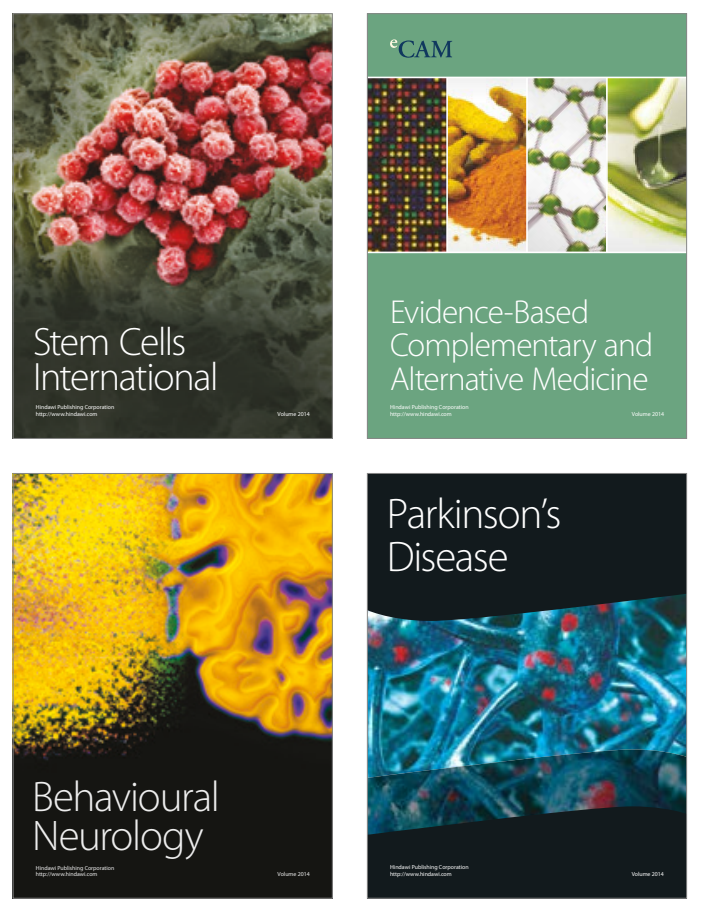
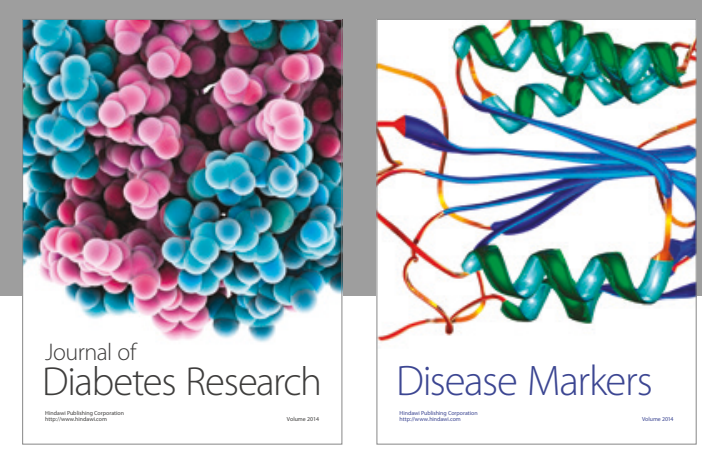

Disease Markers
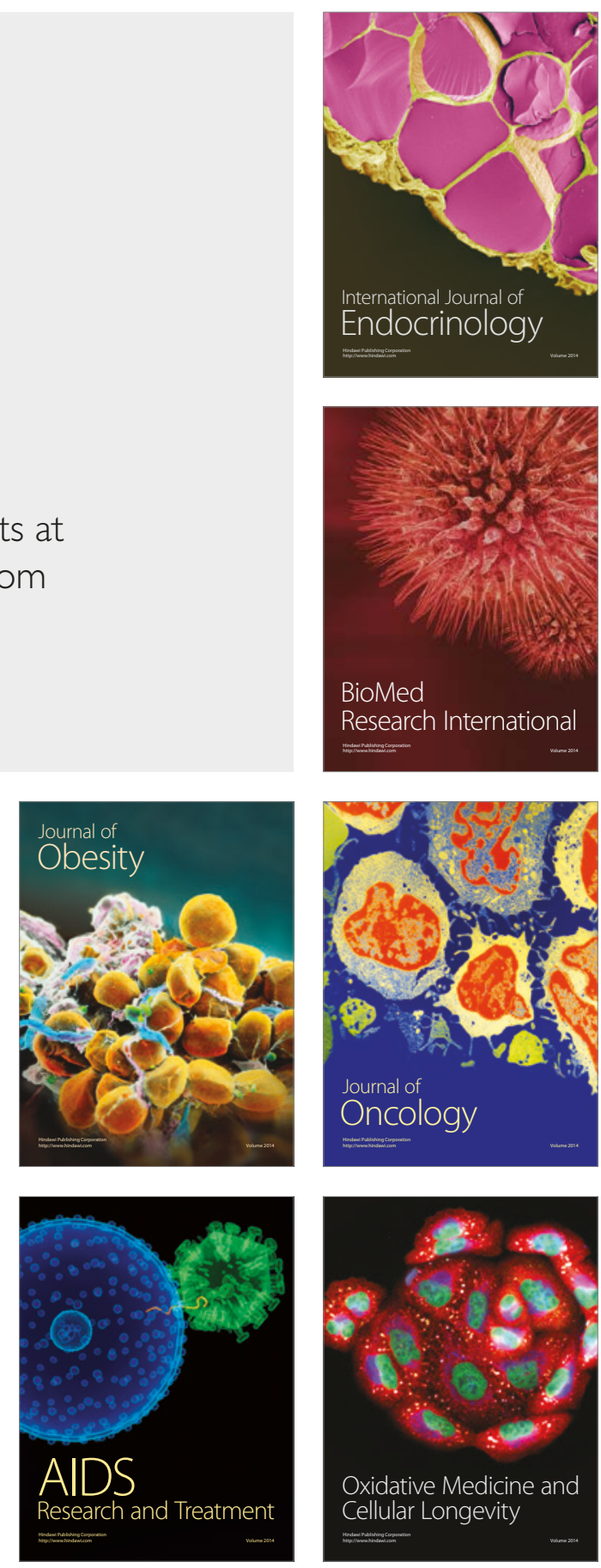